\title{
PEAT FOREST HEALTH ANALYSIS ON LANDSAT 8 OLI / TIRS IMAGERY USING NDVI METHOD IN KOTAWARINGIN TIMUR REGENCY
}

\author{
${ }^{1}$ Rois Saida Sanjaya, ${ }^{2}$ Mitha Fitria Anggraini, ${ }^{3}$ Mahendra Zhafir Pratama \\ ${ }^{123}$ Departement of Geography, Universitas Negeri Semarang, Indonesia \\ ${ }^{1}$ sanjaya.r.s@students.unnes.ac.id, ${ }^{2}$ mithafitria15@students.unnes.ac.id, ${ }^{3}$ mahendrazhafir@students.unnes.ac.id
}

\begin{abstract}
The degradation of the peatland ecosystem has been a major impact on the local environment as well as its surroundings, such as fires, irreversible drying, and dome collapse. This paper presents the application of satellite remote sensing dan GIS techniques to detect and identify peat forest health in Kotawaringin Timur, Central Kalimantan Province, Indonesia. Mapping the spatial distribution of peat forest health is important for making in land management and mitigation of peatland forest fires. This study uses the integration of GIS software and Landsat 8 OLI/TIRS satellite data to identify peatland health using NDVI in Kotawaringin Timur Regency. This area was picked up as a pilot project area for this research because these areas historically had many fire spots in the last few years. The result data processing of Landsat 8 satellite image shows that 116586,4 hectares of Kotawaringin Timur area are disturbed peatland. Base on the result of Landsat 8 image processing data can be seen some areas of Kotawaringin Timur indicate green color means the peat area, and the health level of the peat forest in Kotawaringin Timur Regency is already in the damaged category.
\end{abstract}

Keywords: Peat forest health, NDVI, GIS, Landsat 8

DOI: $10.33541 /$ sp.v21i3.2257

Sociae Polites : Majalah Ilmiah Sosial Politik

Faculty of Social and Political Science, Universitas Kristen Indonesia

ISSN 1410-3745 print/ ISSN 2620-4975 online

Volume 21, Number 2 (Youth Peatland Conference)

Pages 212-220 


\section{Introduction}

Indonesia is a country with the second-largest peat forest area in the world after Brazil, with a total area of 22.5 million hectares (ha). Over the last few years, massive peat forest fires in western Indonesia have become a serious global issue and have caused significant damage to peatlands (Hope et al., 2005). Illegal logging, land-use change, and forest fires are the main problems that often occur in peat forest areas. In addition, a reduction in the amount of biomass contained in vegetation on peatlands can cause changes in the groundwater level. The degradation that occurs in the peat ecosystem will indirectly cause a high level of vulnerability to forest fires (Miettinen \& Liew, 2010).

The island of Kalimantan is the area that most frequently experiences peat forest fires in Indonesia. Peatlands on the island of Kalimantan reach 5.7 million hectares. Of the total peatland area on the island of Kalimantan, around 2.7 million hectares are located in the province of Central Kalimantan. One of the areas in Central Kalimantan Province with quite complex peat problems is Kotawaringin Timur Regency, which has a high incidence of forest fires and occurs almost every year during the dry season. Based on BMKG monitoring, there were 3,799 hot spots scattered in several sub-districts in Kotawaringin Timur Regency (Datmika, 2020). As we know, the existence of the peat ecosystem and the vegetation that lives in it has a very important role in preserving nature, preventing seawater intrusion, and controlling the global climate (Febriani et al., 2018).

Remote sensing is a tool that can be easily used for the detection and monitoring of the earth's surface conditions spatially and multitemporal (Segah et al., 2010). The use of satellite image data through vegetation index extraction is now widely used for the detection and monitoring of vegetation conditions. The vegetation index has a high correlation with the detection of vegetation health (Connell et al., 2010).

Vegetation index analysis is one approach to determine the condition of forests, both those that have experienced fires and those that have not experienced fires (Yusuf, 2000). The aim of this study is to present the application of satellite remote sensing and GIS techniques to detect and identify peat forest health in Kotawaringin Timur regency, Central Kalimantan Province, Indonesia.

\section{Literature Review}

\subsection{Peatland Health}

Peatland island whose soil is formed due to the accumulation of semi-decomposed plant debris so that it has a high organic content (Febria, 2018). Tropical peatland ecosystems are the largest peatland ecosystems in the world, located in Southeast Asia. Peatlands have an important role in influencing the global climate system. Biodiversity in tropical peatlands, which is incorrect in land-use policies, has resulted in widespread degradation of peatlands (Dohong et al., 2017). Most of the peatlands are still in the form of forest cover and are a habitat for various types of flora and fauna. Peat forest is an extraordinary ecosystem where it is a large unit of biodiversity, one of which there are several rare species such as endangered animals and plants (Randi, 2014).

In tropical regions such as Southeast Asia, peatlands are global carbon sinks that play an important role in conserving biodiversity. However, currently, many peatlands are converted to agricultural land and even degraded into non-forest vegetation that is prone to fire (Blackham et al., 2014). Over the past two decades, human activities in the peatland ecosystem have increased rapidly. This causes the destruction of peatlands and is prone to fires (Miettinen and Liew, 2010). Forest damage that occurs, among others, occurs due to 
logging for various purposes, which causes the opening of forest areas so that the peat swamps that were initially flooded with water become dry. This was exacerbated by the occurrence of fires, which caused the opening of the canopy, thus widening the forest on peatlands (Yusuf, 2000).

Kalimantan has a very large diversity of plant species, spread over forest types that have complex and unique ecosystems, one of which is peat swamp forest. Peat swampland has an important role in maintaining environmental balance. Peat swamp land functions as a water reservoir, carbon sink and storage, climate change, and increasingly threatened biodiversity (Daryono, 2009).

\subsection{Landsat $8 \mathrm{OLI}$}

Information related to forest destruction is needed to determine the rate of forest destruction, which can be used as a reference for reforestation or forest function restoration. One solution that can be done for monitoring very large forest areas and to find out very complex forest problems is to use satellite image data (Lonita et al., 2015).

Landsat 8 is actually more suitable to be called the successor satellite of Landsat 7. This is because the characteristics of Landsat 8 are similar to Landsat 7, both resolution (spatial, temporal, spectral), correction method, flying height, and satellite characteristics, sensor brought. It's just that there are additional improvements from Landsat 7, such as the number of bands, the lowest electromagnetic wave spectrum range that the sensor can capture, and the bit value (Digital Number Value Range) of each image pixel. Based on the USGS publication, the Landsat 8 satellite flies at an altitude of $705 \mathrm{~km}$ from the earth's surface and has a scan area of $170 \mathrm{~km} \times 183 \mathrm{~km}$ (Purwanto, 2015).

The Landsat 8 Operational Land Imager (OLI) sensor makes earth observations at eight-day intervals. Improvements to the new Landsat 8 sensor design, including narrower near-infrared waves, higher signal-to-noise ratio (SNR), and greater radiometric sensitivity, highlight the need to investigate the nature of ground observations, particularly their consistency with data from sensors previous satellites (Ke at al., 2015). This algorithm uses the OLI Coastal aerosol band $(0.433-0.450 \mu \mathrm{m})$, which is very helpful in regaining aerosol properties, as it covers a shorter wavelength than the conventional Landsat, TM, and ETM + blue bands. Cloud shadow masks and cloud shadow masks have also been developed using the "cirrus" band $(1,360-1,390 \mu \mathrm{m})$ available on OLI and the thermal infrared band from the Thermal Infrared Sensor (TIRS) instrument (Vermote, 2016).

The OLI (image sensor) instrument design displays multispectral images with a push broom architecture. The push broom implementation is considered to be more geometrically stable than the whiskbroom scanners on the ETM + instrument in Landsat-7 (NASA, 2008 in Sitanggang, 2010).

\subsection{Normalized Difference Vegetation Index (NDVI)}

The technology of the satellite system and digital signal processing algorithms make it easier to retrieve information related to the vegetation on earth more efficiently and accurately. Various kinds of vegetation index processing algorithms can be used to determine the state of vegetation on the land surface, including the Soil Adjusted Vegetation Index (SAVI), Perpendicular Vegetation Index (PVI), Atmospherically Resistant Vegetation Index (ARVI), Enhanced Vegetation Index (EVI), Global Environment Monitoring Index (GEMI), and Normalized Difference Vegetation Index (NDVI) (Lonita et al., 2015). The vegetation index is a remote sensing metric for ecosystem monitoring, and assessment of soil surface 
processes; the Normalized Difference Vegetation Index (NDVI) is one of them (Ke at al, 2015).

The Normalized Difference Vegetation Index (NDVI) is the algorithm most often used in vegetation indices. The principle of the NDVI formula itself is that radiation and visible red light are absorbed by the chlorophyll green leaves so that they will be reflected low, while near-infrared radiation will be strongly reflected by the mesophyll structure of spongy leaves. The range of this index is - 1.0 to 1.0 (Arhatin, 2007 in Kawamuna, 2017). NDVI transformation is a standard product from NOAA (National Oceanic and Atmospheric Administration), a weather satellite whose orbit is polar but gives special attention to global vegetation and weather phenomena. On the African continent, this transformation is widely used for various studies related to changes in vegetation coverage (Danoedoro P, 2012 in Lonita et al., 2015)

NDVI provides information on the productivity and phenology of vegetation temporally and spatially. This algorithm has been widely used for ecological studies (for reviews, see Kerr \& Ostrovsky 2003; Pettorelli et al. 2005 in Hamel 2009). The vegetation index is an important remote sensing metric for ecosystem monitoring and assessment of soil surface processes, among which the Difference Normalized Vegetation Index (NDVI) is the most widely used.

\section{Research Methods}

The research location was conducted in East Kotawaringin Regency, Central Kalimantan, which is one of the areas with quite complex peat problems. Kotawaringin Timur Regency has located between 11207'29 "East Longitude to 113014'22" East Longitude and 1011 '50 "South Latitude to 3018'51" South Latitude. The data used in the research is Landsat 8 imagery, which has a recording time of 7 August 2020. The image used is sourced from the USGS (United States Geological Survey), which is downloaded via the website https://earthexplorer.usgs.gov/.

The Normalized Difference Vegetation Index or NDVI method is an index used to monitor vegetation conditions. The bands used are infrared (NIR) waves and red waves (Red). Infrared waves and red waves are waves that are sensitive to chlorophyll in vegetation. This is why, in this study, the NDVI method was used to determine the health level of peatlands.

The formula for calculating the NDVI value is expressed by the following equation (Lufilah et al., 2017; Carlson and Ripley, 1997; Šimanauskienė et al., 2019):

$$
\mathrm{NDVI}=\frac{(\mathrm{NIR}-\mathrm{RED})}{(\mathrm{NIR}+\mathrm{RED})}
$$

NDVI : Normalized Difference Vegetation Index

NIR : Near Infrared Wave Band Channel

Red : Red Wave Band Channel

The atmospheric disturbance is one of the weaknesses in using the NDVI algorithm. Atmospheric disturbances can cause NDV values to be very low. Small aerosol particles will cause the NDVI value to increase, while large aerosol particles will cause the NDVI value to decrease. The NDVI extraction flow is presented in the following flowchart. 
Figure 1. Research flowchart

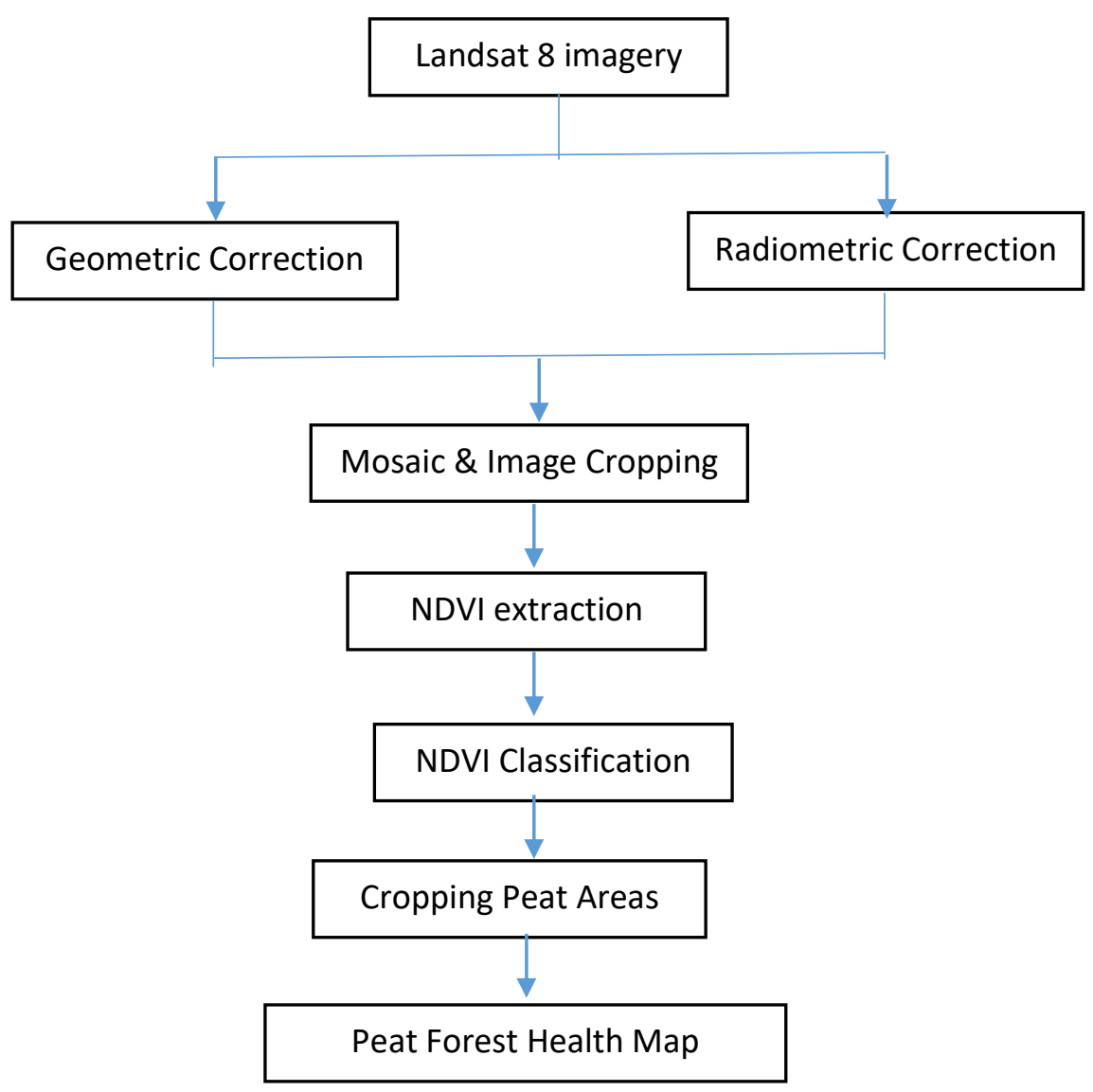

\section{Results and Discussions}

Figure 2. NDVI Classification Map Kotawaringin Timur Regency

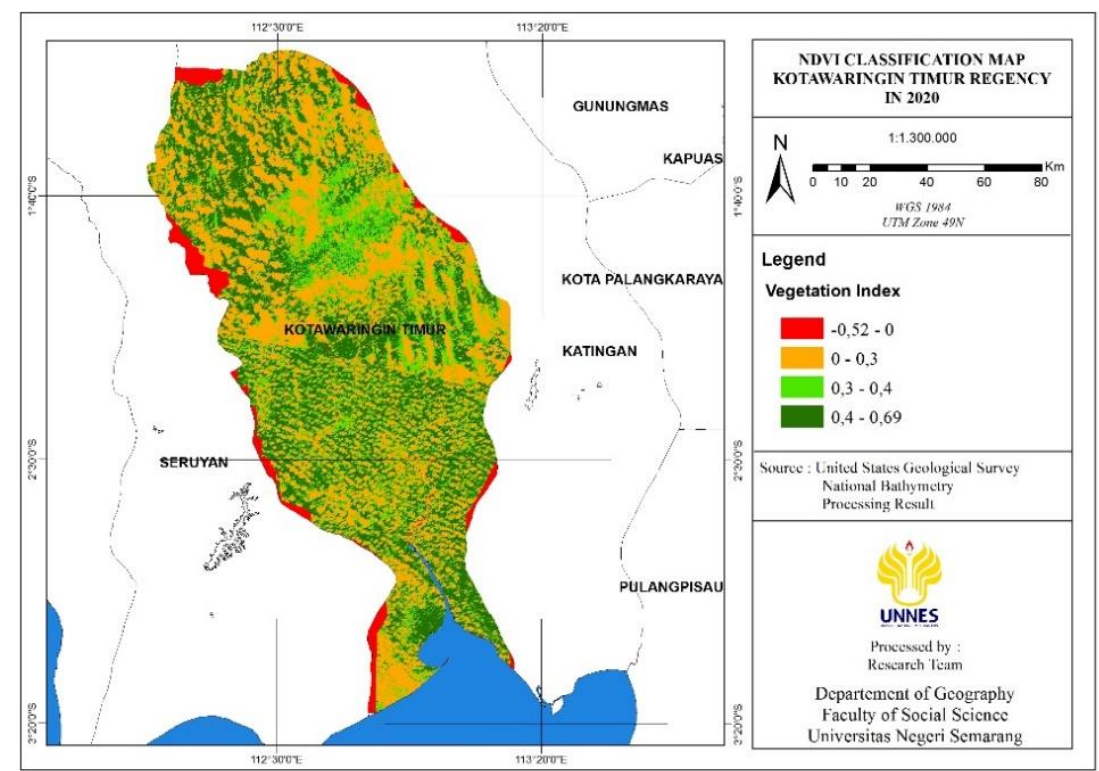


In several studies, NDVI has been used to monitor the condition of peat forests (McPartland et al., 2019). In NDVI, a positive pixel value describes the relative density of vegetation. The higher the NDVI value, the denser the vegetation cover. Therefore, a high NDVI value is interpreted as vegetation with a dense canopy or forest (Syam'ani et al., 2016). Based on the results of NDVI extraction in the study area using Landsat 8 imagery based on the equation formula (1), the NDVI value range ranges from -0.52 to 0.69 . NDVI classifications for water objects range from -1 to 0; NDVI for non-vegetation between 0 to 0.3; NDVI for non-forest vegetation ranges from 0.3 to 0.4 ; while the NDVI for forest vegetation is above 0.4 (Arifin et al., 2020). The following is a map and table of NDVI classification results in East Kotawaringin Regency using processed Landsat 8 imagery.

Table 1. Results of the NDVI Classification of East Kotawaringin Regency

\begin{tabular}{|c|c|c|c|}
\hline Object & $\begin{array}{c}\text { NDVI Value } \\
\text { Range }\end{array}$ & Area (Ha) & $\begin{array}{c}\text { Percentage } \\
(\%)\end{array}$ \\
\hline Water & $-0,52-0$ & 58830,47 & 3,24 \\
\hline Not Vegetation & $0-0,3$ & 982852,57 & 54,13 \\
\hline Non-Forest Vegetation & $0,3-0,4$ & 318879,72 & 17,56 \\
\hline Forest Vegetation & $0,4-0,69$ & 513964,85 & 28,31 \\
\hline
\end{tabular}

Based on the NDVI classification results of East Kotawaringin Regency, the land cover is dominated by non-vegetation objects with a percentage of $54.13 \%$ of the total area of East Kotawaringin Regency, while for forest vegetation, the area is $28.31 \%$, non-forest vegetation objects are $17.56 \%$, and water objects by $3.24 \%$.

From the results of the NDVI classification, Kotawaringin Timur Regency using Landsat 8 imagery, it is not known the area of peatland in Kotawingintimur, therefore in this study to identify the area of peatland using digital data on peatland area from the Ministry of Agriculture. Based on the image processing, the area of peatland in the research location reaches $312711.4 \mathrm{Ha}$, or $16.68 \%$ of the total area of East Kotawaringin Regency, and is scattered in the southern part. NDVI extraction and cropping areas for the health classification of peat forests in East Kotawaringin Regency are presented in the following map and table.

Figure 2. Health Map for Peat Forest in Kotawaringin Timur Regency

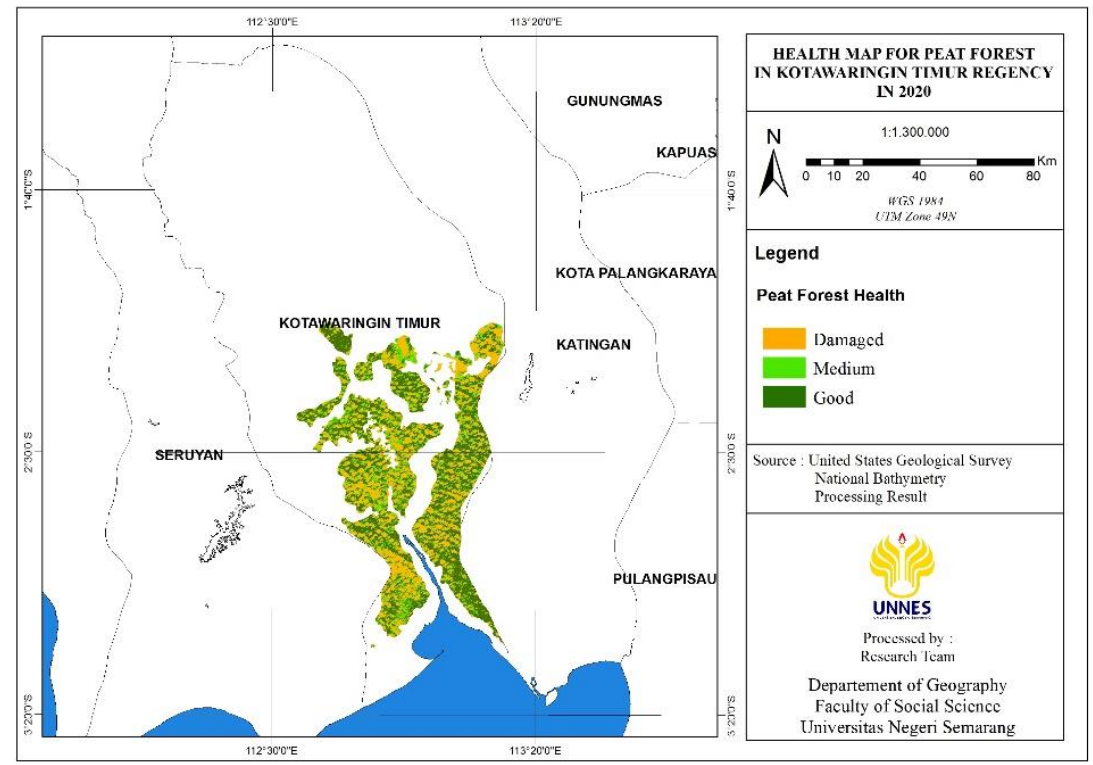


Table 2. Health Classification of East Kotawaringin Peat Forest

\begin{tabular}{cccc}
\hline $\begin{array}{c}\text { NDVI Value Range } \\
\text { for Peat Areas }\end{array}$ & Criteria & Area (Ha) & $\begin{array}{c}\text { Percentage } \\
(\mathbf{\%})\end{array}$ \\
\hline $0-0,3$ & Damaged & 116586,4 & 37,28 \\
\hline $0,3-0,4$ & Medium & 64665,68 & 20,68 \\
\hline $0,4-0,69$ & Good & 131459,3 & 42,04 \\
\hline \multicolumn{4}{r}{ (Source: Landsat 8 Image Data Processing, 2020) } \\
\hline
\end{tabular}

Based on the health classification table for peat forest in East Kotawaringin, it is known that the condition of the peat forest is in bad condition covering an area of 116586.4 $\mathrm{Ha}$ or $37.28 \%$ of the total area of the peat forest. Meanwhile, the health of the peat forest in moderate condition was 64665.68 hectares or $20.68 \%$ and in good condition was 131459.3 hectares or $42.04 \%$. From the results of image data processing, it is known that more than one-third of the peat forest area in East Kotawaringin has been damaged, mostly due to forest fires and illegal logging.

\section{Conclusions and Recommendations}

The NDVI method by utilizing Landsat 8 imagery can be applied for monitoring vegetation cover and information regarding the percentage area of vegetation cover in the research location. Based on the results of Landsat 8 satellite imagery data processing shows that $11,656.4$ hectares or $37.28 \%$ of the peat area in East Kotawaringin Regency is in a bad category (disturbed), and the health level of the peatlands is included in the damaged category. Therefore, peatland forest restoration activities need to be a common concern, especially the government. 


\section{BIBLIOGRAPHY}

\section{Journals/ Articles}

Arifin, S., Carolita, I., \& Kartika, T. (2020). Aplikasi Model Geobiofisik NDVI Untuk Identifikasi Hutan pada Data Satelit LAPAN-A3. Jurnal Penginderaan Jauh dan Pengolahan Data Citra Digital, 16(2).

Blackham, G. V., Webb, E. L., \&Corlett, R. T. (2014). Natural regeneration in a degraded tropical peatland, Central Kalimantan, Indonesia: Implications for forest restoration. Forest Ecology and Management, 324, 8-15.

Carlson, T. N., \& Ripley, D. A. (1997). On the relation between NDVI, fractional vegetation cover, and leaf area index. Remote sensing of environment, 62(3), 241-252.

Connell, J. O., Connolly, J., \& Holden, N. M. (2010). Vegetation Indices For The Detection Of Vegetation Disturbance On Irish Peatlands. Biosystems Engineering Research Review 15, 73.

Daryono, H. (2009). Potensi, permasalahan dan kebijakan yang diperlukan dalam pengelolaan hutan dan lahan rawa gambut secara lestari. Jurnal Analisis Kebijakan Kehutanan, $6(2)$.

Dohong, A., Aziz, A. A., \& Dargusch, P. (2017). A review of the drivers of tropical peatland degradation in South-East Asia. Land Use Policy, 69, 349-360.

Febria, D. (2018). Pengembangan Model Literasi Kesehatan Lingkungan Dalam Menjaga Ekosistem Lahan Gambut Secara Berkelanjutan. EcoNews, 1(2), 64-71.

Febriani, W., Anggoro, B. S., Komala, R., \& Agustina, S. (2018). Explorasi Dan Identifikasi Hijauan Potensial Di Lahan Gambut Kotawaringin Barat Kalimantan Tengah. Biosfer: Jurnal Tadris Biologi, 9(1), 100-113.

Hamel, S., Garel, M., Festa-Bianchet, M., Gaillard, J. M., \&Côté, S. D. (2009). Spring Normalized Difference Vegetation Index (NDVI) predicts annual variation in the timing of peak fecal crude protein in mountain ungulates. Journal of Applied Ecology, 46(3), 582-589.

Hope, G., Chokkalingam, U., \& Anwar, S. (2005). The stratigraphy and fire history of the Kutai Peatlands, Kalimantan, Indonesia. Quaternary Research, 64(3), 407-417.

Kawamuna, A., Suprayogi, A., \&Wijaya, A. P. (2017). Analisis Kesehatan Hutan Mangrove Berdasarkan Metode Klasifikasi Ndvi Pada Citra Sentinel-2 (Studi Kasus: Teluk Pangpang Kabupaten Banyuwangi). Jurnal Geodesi Undip, 6(1), 277-284.

Ke, Y., Im, J., Lee, J., Gong, H., \&Ryu, Y. (2015). Characteristics of Landsat 8 OLI-derived NDVI by comparison with multiple satellite sensors and in-situ observations. Remote Sensing of Environment, 164, 298-313.

Lonita, B. I., Prasetyo, Y., \& Haniah, H. (2015). Analisis Perubahan Luas Dan Kerapatan Hutan Menggunakan Algoritma Ndvi (Normalized Difference Vegetation Index) Dan Evi (Enhanced Vegetation Index) Pada Citra Landsat 7 Etm+ Tahun 2006, 2009, Dan 2012 (Studi Kasus: Kabupaten Kendal, Provinsi Jawa Tengah). Jurnal Geodesi Undip, 4(3), 112-120.

Lufilah, S. N., Makalew, A. D., \& Sulistyantara, B. (2017). Pemanfaatan citra landsat 8 untuk analisis Indeks Vegetasi di DKI Jakarta. Jurnal Lanskap Indonesia, 9(1), 73-80.

McPartland, M. Y., Kane, E. S., Falkowski, M. J., Kolka, R., Turetsky, M. R., Palik, B., \& Montgomery, R. A. (2019). The response of boreal peatland community composition and NDVI to hydrologic change, warming, and elevated carbon dioxide. Global change biology, 25(1), 93-107. 
Miettinen, J., \& Liew, S. C. (2010). Status of peatland degradation and development in Sumatra and Kalimantan. Ambio, 39(5-6), 394-401.

Purwanto, A. (2016). Pemanfaatancitra Landsat 8 untukidentifikasi Normalized Difference Vegetation Index (NDVI) di kecamatan silat hilir kabupaten Kapuas Hulu. Edukasi: Jurnal Pendidikan, 13(1), 27-36.

Randi, A., Manurung, T. F., \&Siahaan, S. (2014). Identifikasi jenis-jenis pohon penyusun vegetasi gambut taman nasional danau sentarum kabupaten Kapuas hulu. Jurnal Hutan Lestari, 2(1).

Segah, H., Tani, H., \& Hirano, T. (2010). Detection of fire impact and vegetation recovery over tropical peat swamp forest by satellite data and ground-based NDVI instrument. International Journal of Remote Sensing, 31(20), 5297-5314.

Šimanauskienė, R., Linkevičienė, R., Bartold, M., Dąbrowska-Zielińska, K., Slavinskienė, G., Veteikis, D., \& Taminskas, J. (2019). Peatland degradation: The relationship between raised bog hydrology and normalized difference vegetation index. Ecohydrology, 12(8), e2159.

Sitanggang, G. (2010). Kajian pemanfaatan satelit masa depan: sistem penginderaan jauh satelit LDCM (LANDSAT-8). Berita Dirgantara, 11(2).

Syam'ani, S. A., Fithria, A., Sofia, L. A., \& Saidah, S. (2016). Delineasi Otomatis Hutan Mangrove dari Citra LDCM menggunakan metode Hibrid Normalized Difference Vegetation Index (NDVI) dan Normalized Difference Water Index (NDWI).

Vermote, E., Justice, C., Claverie, M., \& Franch, B. (2016). Preliminary analysis of the performance of the Landsat 8/OLI land surface reflectance product. Remote Sensing of Environment, 185, 46-56.

Yusuf, R. (2000). Analisis Vegetasi Dan Degradasi Jenis Tumbuhan Hut An Gambut Setelah Kebakaran Dikawasan Taman Nasional Tanjung Puting Kalimantan Tengah. Berita Biologi, 5(3), 277-283.

\section{Thesis}

Datmika, Rafi. (2020). Analisis Kebakaran Hutan Dan Lahan Di Kabupaten Kotawaringin Timur Menggunakan Sistem Informasi Geogerafis (Skripsi, Institut Teknologi Nasional Malang). 